Vol. 1, No. 2

Vitoria - ES, Jun - Dec. 2004

p. $74-88$

\title{
Accounting Disclosure: Publication of Social/Environmental and Financial Aspects in Accounting Statements ${ }^{\mathrm{i}}$
}

\author{
Flávia Zóboli Dalmácio \\ FUCAPE - Capixaba Foundation for Research in Accounting, \\ Economy and Finance
}

\author{
Francislene F. M. de Paulo \\ UNIVEN - Capixaba College of Nova Venécia
}

\begin{abstract}
Accounting constantly seeks to transform data and registers into useful, relevant and transparent information to serve the needs of as many people as possible. Since these needs and the level of knowledge among investors and other interested parties differs widely, we seek to address the question of the best way to disclose accounting information, to facilitate comprehension and interpretation of the social/environmental and financial aspects of interest to particular individuals. To do this, we conducted a bibliographical and documentary study using a sample of the financial statements published by industrial corporations in the state of Espírito Santo in 2003, covering the 2002 fiscal year. We found that the way such information is disclosed ranged from simple notes to the financial statements to more elaborate presentations in annual reports of management. We judged the latter to be a more flexible and interesting method of disclosing such information, based on the objectives proposed and theoretical references, considering the proxies used.
\end{abstract}

Key-words: accounting disclosure, social, environmental, financial.

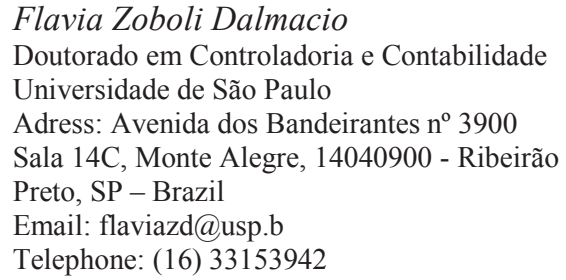

Telephone: (16) 33153942

${ }^{\mathrm{i}}$ Article presented at the $4{ }^{\text {th }}$ USP Congress of Control and Accounting.

Francislene F. M. de Paulo

Doutorado em Controladoria e Contabilidade

UNIVEN - Capixaba College of Nova

Venécia - ES - Brazil

Telephone: (16) 33153942 


\section{INTRODUCTIION}

he purpose of accounting is to generate various types of information to enable T diverse users to make decisions. This information must be useful, relevant, accurate and timely. The data recorded in a company's accounts are transformed into financial statements and their explanatory notes. These are published to make public the company's financial situation. Nevertheless, a significant part of the outside public (customers, suppliers, financiers, investors, the public at large, etc) has difficulty understanding the information contained in these statements due to their highly technical nature.

Outside users, especially in Brazil due to its concentrated pattern of shareholding (LOPES, 2002), do not have access to the internal company reports that serve as the bases for published financial statements. There is a need for more information to be made available than is the case now, to enable a better interpretation and analysis of the data presented. Interested people, in possession of the statements, should be able to evaluate the company's situation, whether it is really profitable, if it valorizes its employees and is concerned about the social and environmental aspects of its activities.

There is a need for greater transparency in the accounting information divulged, to make it more comprehensible to all interested parties. This has the added benefit of reducing the chances for irregularities and fraud. It is thus necessary to discuss ways to improve the methods of presenting accounting information. The information published must be relevant not just for the company, but for all stakeholders as well (IUDÍCIBUS, 2000).

Among the items required by Brazil's Law of Corporations (Law 6404/76), only the annual report and the notes to the financial statements permit a better grasp of the company's situation and policies and allow the inclusion of some financial indicators.

With the possibility of including in the annual reports and notes information to serve the interests of various people, facilitating an understanding of the accounts, these should become true aids particularly to outside parties.

The difficulty of understanding the financial statements can cause people to lose interest in the information they contain. This leads to the question: What are the best ways to disclose, in the annual report and notes to the financial statements, information that helps as many parties as possible to interpret the accounts regarding the company's social/environmental and financial aspects?

The general aim of this work is to identify complementary information that, if published in the annual report and notes to the accounts, would improve their comprehension regarding the social/environmental and financial aspects. To attain this goal, we examine two specific objectives: (1) the disclosure of relevant information on socio-environmental aspects; and (2) the publication of financial performance indicators, such as liquidity, profitability and capital structure.

This work is restricted to the annual reports and explanatory notes published in newspapers, homepages and magazines by corporations in the industrial sector of the state of Espírito Santo.

We start from the hypothesis that these companies are concerned with the transparency of their statements, and seeking their consideration by external users, publish accessible information by means of transparent and objective statements containing textual information, graphs and tables on social aspects, beyond just financial indices. This maximizes the esteem the public has for these companies. 


\section{THEORETICAL REFERENCE}

\subsection{Evolution of Accounting}

Accounting arose from the need for people to control their property and wealth. Some historical facts in human history have given particular impetus to the development of accounting, among these the discovery of paper, the creation of money, the development of printing, the rise of capitalism, the Industrial Revolution and the Great Depression, among others. "Keeping count of property and wealth has been a preoccupation of human societies since the dawn of recorded history, and mankind has had to continually perfect the instruments for valuing assets as economic activities have grown in size and complexity." (IUDÍCIBUS, 2000, p.30)

With the development of societies, accounting procedures have been evaluated, theories and practices have arisen through processes of deduction and induction, until we have arrived at our current state of the art. Since accounting is an applied social science, it is constantly evolving, through research, measurement of intangible assets, concern with the way the information is shown, always striving to meet its main objectives.

\subsection{Objectives of Accounting}

Among the various authors studied, there are diverse ideas on the objectives of accounting. According to Iudícibus (2000, p. 19), either we consider accounting's objective to be supplying to readers, regardless of their nature, a basic set of information that presumably should equally serve all types of users, or it should be able and responsible for presenting totally differentiated lists of information for each type of user. (our emphasis)

According to this view, the ideal is to provide users with a basic repository in which each reader according to his need and way of deciding can obtain the accounting information desired, giving emphasis to that which is considered most important.

According to Iudícibus, Martins and Gelbecke (2000, p. 43), the main goal of accounting "is to permit each main group of users to evaluate the financial health of the enterprise in a static sense, as well as to make inferences about its future tendencies."

This definition adds to accounting's aims the discernment of future tendencies. The financial statements refer to a certain period, the fiscal year, which in Brazil corresponds to the calendar year, terminating on December 31st of each year. The information refers to that moment. It is a snapshot of the firm's situation at the end of each year. But this does not rule out the possibility of using it as a basis to judge the likelihood of future events. For many, if not most, users the predictive nature of the accounts is the main interest.

Also on the objective of accounting, Hendriksen and Breda (1999, p. 120) define it by looking at the financial situation. To them "the objective of accounting is to supply a set of financial reports for users undecided about the wealth or economic transactions of the firm."

The National Accounting Council, in its Resolution 774/94, presents the objective of accounting as: "the correct presentation of the equity and the presentation and analysis of its causes and changes. Under a pragmatic prism, the application of accounting to a particular enterprise seeks to provide the users with information on the aspects of an economic, financial and physical nature of the entity's equity and its changes, which includes registers, demonstrations, analyses, diagnoses and prognoses, expressed in the form of reports, opinions, tables, spreadsheets and other means." (our emphasis) 
In common, all concepts of the objectives covered in this topic refer to users. Hence, accounting must serve them first, with the information that interests them. The difficulty, then, is to learn the decision model of each user.

\subsection{Users of Accounting Information}

Iudícibus, Martins and Gelbcke (2000, p. 43) conceptualize users as "all natural and legal persons that have an interest in evaluating the situation and progress of a determined enterprise, whether that enterprise is a company, nonprofit institution or family business."

If the main objective of accounting is to serve users, it is necessary to define who these users are and what type of information they want. For the purposes of this work, we consider classify users into internal and external ones. Internal users are those who work directly with the accounting information or have access to it within the company. External users do not have direct access to this information, and can be employees, customers, suppliers, society, the government - all those interested in the company's financial and social situation.

For accounting statements to satisfy these users effectively, it is necessary to maximize the relevant information, avoiding useless and irrelevant information. To reach and serve the interests of outside users, accounting should study and prepare the best way to present its statements.

\subsection{Disclosing Accounts}

To disclose is to make evident, to show clearly, without doubt, in a way that can be promptly understood. Perhaps we can unify these concepts and say that disclosure means showing clearly, conveying immediate comprehension to what is being communicated (AQUINO and SANTANA, 1992, p. 1, our emphasis).

According to the American Institute of Certified Public Accountants (AICPA ) (1961, quoted in IUDÍCIBUS, 2000, p. 117), accounting information should disclose relevant information, without exaggeration that can cloud and confuse those who are analyzing it. Hence, "the accounting statements should disclose what is necessary in a way that is not misleading." Besides this, accounting information should be made available in timely fashion, enabling making decisions at the proper moment, serving the principle of opportunity. The principle of opportunity refers simultaneously to the timeliness and integrity of the records of the company's equity and its changes, promptly and to the correct extent, regardless of the causes (Federal Accounting Council, Resolution 750/93, Art. 6, our emphasis).

Timeliness demands that the accounting information be registered at the moment it occurs, avoiding incomplete or out-of-date statements. Besides timeliness and integrity, Iudícibus (2000, p. 77) suggests that accounting information should have other qualities, among them reliability, comparability and comprehensibility. Reliability is the quality (attribute) that allows users to accept the information and use it as a basis for decisions. Comparability should enable users to discern among different enterprises. Comprehensibility reveals the quality of the accounting information, which should be displayed in a way that is as easily understood as possible, enabling users to effectively understand it and use it to make decisions.

Iudícibus, in stressing the qualities of the information, indicates those that lead to satisfying users efficiently. For accounting information to be comparable, it must be based on consistent criteria. Normally the financial statements are published with the results of the current and past year, allowing users to compare them. This does not mean that the accounting criteria cannot be modified, but if this happens, the changes must be made clear in some way.

According to Iudícibus (2000, p. 121), the way information is displayed should "present qualitative and quantitative information in ordered fashion, leaving as little as 
possible out of the formal statements, in order to provide an adequate base of information for users." This author points out that it is not appropriate to overload the notes with additional details. The purpose of notes should be to keep qualitative information from becoming subjective, which hinders its disclosure.

Besides this, Iudícibus (2000, p. 117) also stresses the relation between disclosure and the convention of materiality. All information disclosed should be relevant and material for users. The accountant, in preparing the statements for publication, needs to perceive that these statements are the most evident process of communicating with external users.

"The communication process implies recognizing the types of information necessary to users of accounting information and an assessment of their ability to adequately interpret the information." (LOUZADA, 2002, p. 19) The ability to analyze accounting information should rest with the accountant or other qualified professional. The accounting reports should be prepared considering that they will be analyzed by individuals with a good grasp of accounting procedures and principles, who will interpret and translate what the statements say in the simplest terms to their clients (IUDÍCIBUS, 2000, p. 118).

Or still, "the interpretation of the accounting statements is the sole and exclusive task of experts in accounting and finance, who should be the intermediaries between companies and their owners, assisting the latter in their analyses." (IUDÍCIBUS, 2000, p.117)

In order to attain transparency in the statements prepared, the accountant can use all forms of disclosure known.

\subsubsection{Forms of Disclosure}

Information between parentheses, footnotes, graphs, charts and supplementary statements are all ways to disclose accounting information. However, these methods should be instruments to complement the financial statements themselves, to give further information on the company.

The main forms of disclosing accounting information are: the balance sheet; statement of income; statement of changes in financial position; statement of changes in stockholders' equity; statement of accrued profits or losses; notes to the financial statements; the opinion of the independent auditors; and the annual report of management. In this work, we focus on the notes and annual report.

\subsubsection{Notes to the Financial Statements}

The publication of notes is established by the Law of Corporations, whose Article 176, $\S 4$, provides that "Financial statements shall be supplemented by explanatory notes and other analytical charts or statements necessary to clarify the status of assets, liabilities and income" (Art. 176,). Art. 176, § 5, lists some items that must be stated in the notes: (a) the principal evaluation criteria used for assets (especially inventories) and liabilities, for depreciation, amortization, and depletion calculations, for the constitution of provisions or allowances, and for calculating the reflection of unrealized losses of assets; (b) investments in other corporations, when considered relevant; (c) revaluation surpluses; (d) in rem charges on assets, any guarantees given to third parties, and any contingent liabilities; (e) interest rates, maturity dates, and guarantees of long-term liabilities; (f) number, types, and classes of shares; (g) stock call options granted and exercised during the fiscal year; (h) adjustments stemming from previous fiscal years; (i) any events subsequent to the close of the fiscal year which have or which may have a relevant effect on the financial standing and future income of the corporation. Besides these, the Brazilian Securities Commission (Comissão de Valores 
Mobiliários - CVM) recommends the disclosure of other notes, considered as relevant information to outside users.

We analyze the notes in this work seeking to evaluate their capacity to divulge complementary information the statements proper, in this way disclosing social aspects and financial indices, using charts, graphs and text, to facilitate interpretation by readers.

\subsubsection{Annual Report of Management}

The annual report, according to Iudícibus, Martins and Gelbcke (2000, p. 398), "represents a necessary and important complement to the financial statements published by a company, in terms to permit the supply of additional data and information that are useful to users in their judgment and the process of reaching decisions."

This report has some characteristics that permit the comprehension of more users, since it is descriptive and less technical, besides "serving as a predictive element of the company's future evolution and results." (IUDÍCIBUS; MARTINS and GELBCKE, 2000, p. 398) These characteristics can be found in the reports when prepared according to the Instructions issued by the CVM and requirements of the Corporate Law.

To assist companies in preparing and publishing their annual report, the CVM has recommended some items that meet the need for informing users and that are already being employed by some companies. Among these we can highlight: description of the business, products and services; comments on the general economic situation; information on human resources; capital expenditures made and planned; research and development; new products and services; protection of the environment; administrative reorganization; investments in subsidiaries and affiliated companies; rights of shareholders; market data; and perspectives and plans for the current and future years. The company is not limited only to these aspects. It can exercise its creativity and good sense to produce the report(CVM).

In its Orientation Finding no. 15, issued on December 28, 1987, the CVM established the items of information that must be contained in the annual report, among them: (a) acquisition of bonds and debentures of its own issue (Art. 55, § 2); (b) policy on reinvesting and profits and distributing dividends; (c) provisions of shareholders' agreements (Art. 118, $\S$ 5); (d) most important business transactions and administrative facts occurring during the year (Art. 133, numeral I); and (e) list of investments in related companies, showing the changes during the year (Art. 243).

Despite these recommendations and standards, in Brazil annual reports are generally considered insufficient in relation to the quality of information, mainly because few companies publish one, or if they do, often in perfunctory form, failing to exploit its informative capacity. A large part of companies publish only the financial statements required by law. Others only publish a short commentary from the executive board, explaining that the presentation of the financial statements is a legal obligation and submitting them to the analysis of shareholders. Still other companies mainly use the annual report as a selfpromotional tool by management, which is not in line with the legal recommendations (IUDÍCIBUS; MARTINS e GELBCKE, 2000).

According to our research here, the annual report can be a good vehicle to disclose social information and financial indices, thus maximizing the value of the information generated and serving the interests of all stakeholders.

\subsection{Social Report}

"The social report seeks to demonstrate the level of social responsibility assumed by the company and thus render accounts to society at large for its use of public patrimony, 
consisting of natural and human resources and the right to live with and enjoy the benefits of the society in which it operates." (IUDÍCIBUS; MARTINS e GELBECKE, 2000, p. 31)

Companies have a social obligation and can no longer simply pursue naked profit. There must be a relationship of respect for the social aspects and also an interest in preserving the environment, since companies are fundamental pieces for a nation's social and economic development.

Investors, financiers, consumers, employees, the state and the environment are the main components of this society that seeks to absorb information on the company's position both from an economic and socio-environmental standpoint (DE LUCA, 1998).

There is a growing concern to analyze the company as a social institution and not just an economic one. Therefore, society has been rewarding those companies that take initiatives to develop social activities related to their employees and society at large and to participate in the process of preserving the environment where they are present (DE LUCA, 1998, p.18). For this to happen, the company needs its statements to be transparent and must seek to supply information to society on its use of human, natural, financial, technological and other resources that belong to society itself (directly or indirectly). This is the minimum that companies should do to deserve the respect and credibility necessary to continue their operations (DE LUCA, 1998, p. 19). (...) From a social perspective, the objective of accounting is to supply information to permit users to evaluate the effects of the company's activities on the society in which it is inserted. (DE LUCA, 1998, p.21)

Users increasingly need and seek social information on the company in the published financial statements. Accounting, then, aiming to satisfy user interests, supplies the social report as an instrument to disclose social information. This statement is not yet obligatory, but its publication can facilitate distinguishing companies that are concerned with social and environmental aspects and those that do not, because they do not publish information in these respects. Society can only take proper note if companies disclose these facts.

According to Júnior and Begalli (2002, p. 272), there is a bill in Congress that would oblige companies with more than 100 employees to disclose a social balance sheet along with the other accounting statements. This does not keep smaller companies from doing the same. This statement will have to contain, among other points, information on the situation of the company's employees, investments in the community and environment.

\subsection{Financial Indices}

"An index is a ratio between accounts or groups of accounts in the financial statements that seeks to show a certain aspect of a company's economic or financial situation." (JÚNIOR and BEGALLI, 2002, p. 235). According to these authors, the objective of analyzing financial information through indicators is to supply useful information to users. It is not necessary to use a huge number of indices, but rather to choose those that best satisfy those interested in the particular firm.

The indices proposed in this work are the most common, those that are easiest to interpret. They are: capital structure, liquidity and profitability. The liquidity and capital structure indices indicate the company's financial situation and mainly use the balance sheet as a source of information. Matarazzo (1998) and Iudícibus (1998), among other authors, present a set of indicators considered ideal to show a company's financial situation. 


\section{METHODOLOGY}

This work was developed using aritcles, books, newspapers, scientific journals, official publications and the Internet on the theme covered. The study is classified as documentary and bibliographical, "the documentary uses materials that have not yet been utilized, the bibliographical is based on the contributions of various authors on the question." (NASCIMENTO, 2002, p. 81)

\subsection{Data Collection}

We collected our data from the financial statements and accompanying reports of industrial corporations in the state of Espírito Santo, published in 2003, referring to the 2002 fiscal year.

To choose the companies, we relied on the 2002 edition of the magazine 150 Maiores Empresas do Espírito Santo ("150 Largest Companies in Espírito Santo"). Among the 150 companies listed, 53 are in the industrial sector, and of these only 39 are corporations (the rest being limited liability companies). For an exploratory character, we conducted the study with 14 of these 39 corporations (36\%).

Later we examined in detail the financial statements of two companies that have received national recognition, winning the Transparency Trophy awarded by ANEFAC (National Association of Financial, Administrative and Accounting Executives), FIPECAFI (Foundation and Institute for Research in Accounting, Actuary and Finance) and SERASA (National Company for Commercial Information). The companies eligible for this award are the 500 largest private and 50 largest government-owned companies in Brazil. This award was given for the past six years, with the winner in 2001 being airplane maker Empresa Brasileira de Aeronáutica S/A (Embraeer), and mining conglomerate Companhia Vale do Rio Doce (CVRD) in 2002, relying on their financial statements and annual reports for 2000 and 2001 respectively. These two companies served as benchmarks for comparison.

The companies considered for the award can come from the commercial, industrial or services sectors, and must have published their financial statements according to the requirements of the Law of Corporations. This award was instituted to recognize those companies that best publish their statements with transparent information, in line with applicable accounting principles and that disclose information of most relevance to users. Information about this award can be found at the ANEFAC site (www.anefac.com.br).

\subsection{Treatment of the Data}

After collecting the data, we analyzed them and singled out the relevant information disclosed in the annual reports and notes to the financial statements, on social/environmental and financial aspects, the latter from the notes and the former from the annual reports. Based on this selection, we were able to respond to the issues of the study.

\subsection{Analysis and Interpretation of the Data}

Analysis and interpretation turn raw data into usable information. We did this analysis by comparing the information obtained from Embraer and CVRD with the companies in the state of Espírito Santo.

It must be stressed that we made no value judgments on the trustworthiness of the registers, since we believe the companies studied enjoy credibility and are faithful to the legal obligations, with ethical and responsible accountants. We also did not evaluate whether or not the indices proposed for analysis and interpretation of the data are effective, since we assumed 
that from among the various performance indicators employed in the market, the companies choose those that best reflect their financial situation.

\section{PRESENTATION OF THE RESULTS}

Presentation of the results of the study begins with a summary of the annual reports and financial statements of our two benchmark companies: Companhia Vale do Rio Doce (CVRD) and Empresa Brasileira de Aeronáutica S/A (Embraer). As described, these two companies are past winners of the Transparency Trophy given jointly by ANEFAC FIPECAFI - SERASA, in 2002 and 2001, respectively. The purpose of this award is to recognize the Brazilian companies that are best at disclosing relevant information, above and beyond the minimum required by law.

Since the objectives focus of social/environmental aspects and financial indicators, it is necessary to present the items disclosed by these two companies that satisfy the needs of various users according to the criteria established bythe organizers of this award.

\subsection{Companhia Vale do Rio Doce}

CVRD published in 2002 its financial statements for 2001, which we consulted via its homepage (www.cvrd.com.br). The financial statements consist of the following items: annual report; management comments; accounting statements (consolidated; notes; socal report; value added statement; cash flow statement.

By analyzing these items, it is possible to identify the information considered relevant and that serves the objectives proposed in this study.

\subsubsection{Financial Aspects}

In its annual report, CVRD provides users with information on its business strategy, corporate governance model, management model, executive compensation plan, purchase and sale of assets, investments in controlled companies, policy on distribution and reinvestment of profits, fund raising, sale of shares and sales records. Besides these, the report also employs financial indices such as EBTIDA, the company's situation against the backdrop of the national and international economies, evaluation of short- and long-term debt and a percentage and quantitative comparison against the previous year of revenue, profits, return on net equity and exports. holdings.

It gives further detail in notes on its subsidiaries and affiliated companies and other

\subsubsection{Social and Environmental Aspects}

After the annual report, the company presents the accounting statements, and also the social report (not legally mandatory) as additional information. This social report contains information on the expenses for employees, percentage of these expenses on gross payroll and gross turnover (sale of products and services). The specific expenses in the social report are: food; compulsory social charges; private pension plan; health; education; profit sharing; and other benefits.

There is also information on employee turnover and the balance of employees at the start and end of the year. CVRD also discloses its expenditures on social and environmental projects.

On the social aspect, the notes disclose the employee pension benefits with the portion paid by the company as sponsor. 
Since CVRD is mainly a mining company, particularly active in the extraction, processing and sale of iron ore, all activities with high environmental impact, the company discloses its spending on reforesting (in notes to the section on property, plant and equipment), the fact that it manages its environmental actions in conformity with the ISO 14001 standards (Environmental Quality System), in order to minimize the impact of its operations. It also discloses in its social report the provision for environmental liabilities (Environmental impacts - real or potential - produced in the past that have not yet been resolved).

\subsection{Empresa Brasileira de Aeronáutica S/A (Embraer)}

Embraer published in 2001 its financial statements for 2000, available from the homepage of the Brazilian Securities Commission (www.cvm.gov.br). For this study, we employed the following items: annual report of management; balance sheet; statement of income; and notes to the financial statements.

\subsubsection{Financial Aspects}

Embraer's annual report is detailed and supplies information in text and graphs that is easy to interpret about the company's financial situation. There were quantitative comparisons of net revenue, net profit and exports for the current versus past year. Besides a description of sales, there was a description of the products manufactured, their breakdown in the overall revenue and their good acceptance in the market.

The following items were also highlighted: presentation of new products, detailing their characteristics; expansion and construction of new factories; main customers and orders; customer satisfaction; trading of the company's shares on world stock exchanges; description of the company's business; expansion of business and the market through strategic alliances and new technologies; investments in research and development of new products; and a statement of value added.

The company discloses its financial indices using a table that contains: indebtedness; return on assets; return on net equity; current liquidity index and inventory turnover. All these indices are compared with the previous year.

The annual report also gives information on the company's social projects, its workforce expansion and total number of employees, revenue per employee, overall employee remuneration (compared with prior years), and also professional training programs, motivation campaigns, technical improvement and updating, and training of new workers (entrance of interns and trainees for possible hiring).

Embraer, in partnership with other companies, develops programs for ongoing improvement of the health and life quality of its employees, both on and off the job. The company demonstrates concern over: prevention and recovery from chemical dependency, general health, high blood pressure, nicotine addiction, obesity, diabetes, cholesterol and physical activity. There is a vitality campaign that includes advice on good posture, stress reduction, healthy diet and physical exercise, and a blood donor campaign.

The company also makes contributions to social service entities. These are shown in its annual report, naming them and the activity of each.

It also discloses the benefits granted to employees, such as food, group life insurance, transportation, medical and pharmacy expenses, the company pension plan (complementary to the INSS, the National Social Security Institute, where part is paid by the company); general health care, and profit sharing. 


\subsubsection{Social and Environmental Aspects}

The annual report also provides information on the environmental projects carried out by Ebraer. Among these are: program for prevention and monitoring of all production areas; ISO 14000 environmental management project; prevention of atmospheric pollution; maintenance of water quality; collection and treatment of all solid waste and organic trash produced by the company.

\subsection{Industries in Espírito Santo}

We examined the financial statements of 14 corporations, classified in 2002 according to the magazine 150 Maiores Empresas do Espírito Santo as being among the 53 largest industrial concerns in the state.

These companies were: Aracruz Celulose S/A; Brametal Brandão Metalúrgica S/A; Carboderivados S/A; Contek Engenharia S/A; CST- Companhia Siderúrgica de Tubarão; Fibrasa S/A Embalagens; Frisa Frigorífico Rio Doce S/A; Chocolates Garoto S/A; Itabrasco Companhia Ítalo-Brasileira de Pelotização; Metalosa Indústria Metalúrgica S/A; Ornato S/A Industrial de Pisos e Azulejos; Rimo S/A Indústria e Comércio; S. A. A Gazeta; and TN Industrial S/A.

\subsubsection{Companies that do not disclose either social/environmental information or financial indices}

The financial statements of Brametal - Brandão Metalúrgica S/A, TN Industrial S/A, Rimo S/A Indústria e Comércio, Ornato S/A Industrial de Pisos e Azulejos, Frisa - Frigorífico Rio Doce S/A and Carboderivados S/A did not contain any information on social or environmental aspects or financial indicators.

The annual report of management or the executive board of these firms consists of at most 10 lines, perfunctorily submitting the financial statements and accompanying documents to the consideration of shareholders, divulging the company policy.

Contek Engenharia S/A and Fibrasa S/A Embalagens did not divulge any such report. The notes of these companies were limited to a few items of those recommended by the CVM and called for by the Law of Corporations (Art. 176).

\subsubsection{Companies that disclose either social/environmental information or financial indices}

Metalosa Indústria Metalúrgica S/A disclosed in notes its employee profit sharing, but it is hard to understand the criteria used due to the lack of details. The report only submits the financial statements to the consideration of shareholders.

Chocolates Garoto S/A uses the annual report in the same way as Metalosa. However, the notes disclose information on the complementary employee retirement program sponsored by the company. The plan is under the auspices of Fundação Garoto de Previdência Social, which also has social and financial assistance programs.

S.A. A Gazeta, in its annual report, reviews the main happenings of the year that influenced the company's economic and financial situation, presenting outlays on new equipment to boost productivity. From a social standpoint, the company has been downsizing its workforce to reduce operating costs. The company's operating result is measured by EBITDA, shown in a graph in the annual report. Its notes to the financial statements are limited to some of the items recommended by the CVM and Law of Corporations (Art. 176). 


\subsubsection{Companies that disclose both social/environmental information and financial indices}

Itabrasco - Companhia Ítalo-Brasileira de Pelotização discloses in its annual report sales revenue, net profit and EBTIDA for the year, compared with the previous year. Besides this, it reports ISO 9001 recertification and the unification of common procedures to ISO 9000 and ISO 14000.

In the environmental area, Itabrasco discriminates, by software, its management of waste, improvement of waste storage center, air quality monitoring, effluent monitoring and epidemiological studies of the impact of air pollution on health of the population.

The notes to Itabrasco's financial statements contain an item on its pension plan, into which the company makes matching contributions.

However, the companies that reveal the most are CST - Companhia Siderúrgica de Tubarão and Aracruz Celulose.

CST divides its annual report into topics, displaying the year's highlights, as follows: (1) Introduction: expansion of business, increase in productive capacity, list of most important events during the year; (2) Operational performance: new products and technologies, export sales, ISO 9001 recertification, new equipment, energy self-sufficiency contributing to improve environmental conditions; (3) Investments: employee professional growth programs, new businesses; (4) Financial performance: EBITDA growth, indebtedness; (5) Capital markets and shareholder return; (6) Corporate governance: concern for improved disclosure of financial and non-financial information; (7) Social report: labor indicators: food, pension plan, health, education, profit sharing; Social indicators: investment in good citizenship, social actions, environmental projects; Labor force indicators: number of employees hired and final balance for the year.

Besides the above items, also standing out are indications on projects for occupational health and safety, programs to encourage better quality of life among workers and their dependents, pay package policy and pension benefits with medical, pharmacy and dental assistance, basic schooling program with an in-house learning facility and a value added statement.

There is news of environmental actions: reuse of industrial wastes; ISO 14001 certification; water treatment; use of gases expelled to produce electricity and reduce environmental impacts.

In its annual report, Aracruz Celulose S/A presents the company itself, its products, production capacity and afterward some relevant information on its strategies and results. This information can be grouped as follows: International scenario: product supply and demand and growth patterns of the world economy; Strategic vision: objectives, installation of new plants, updating of computer systems, alignment of individual and sectorial goals with corporate strategies; Financial performance: comparison of net profit, net operating revenue, cost of products sole and operating and financial expenses for the current and previous years, exchange rate variation, EBITDA, allocation of capital expenditures, cash flow and indebtedness; Internal processes: improved product transport, outsourcing of maintenance activities, efforts to genetically improve eucalyptus, and new technologies; Personnel management: a formal system to accompany the development of operational and administrative personnel, reduction of work-related accidents, internal recruitment and promotion program, hiring of local labor, program to raise the schooling level of employees, encouragement to practice physical activities with reimbursement of $50 \%$ of expenses, rehabilitation program for employees whose original capacity has been reduced, psychological counseling and medications for employees and family members who want to quit smoking; 
Community actions: support for social programs in the region where the company operates, agreement with indigenous communities to promote recuperation of rivers and reforesting; Environmental management: improved forestry management procedures to reduce environmental impacts, obtention of environmental licenses.

In notes the company discloses its percentage contribution of payroll for payment into the private pension plan, cash flow and value added statement as additional information.

\section{PRESENTATION OF RESULTS}

After analyzing Companhia Vale do Rio Doce (CVRD) and Empresa Brasileira de Aeronáutica (Embraer), we found that they fully meet the general and specific objectives of this work. To disclose social and environmental information the two companies do this completely in the annual report (and social report).

From a financial standpoint, CVRD could have used other indices than EBTIDA and the simple information on short- and long-term indebtedness, but on the social/environmental aspect, the social report enriches the information supplied.

Embraer meets the general objectives, and principally the specific ones, through use of graphs, tables and texts on the financial and social/environmental aspects.

As shown in Graph 1, of the companies in Espírito Santo, 57.14\% do not have any disclosure of the proposed objectives of this study. Some of the companies studied $(21.43 \%)$ publish some information on certain social or environmental aspects, but this information is generally not transparent or is only contained in notes, without the necessary display to facilitate interpretation and comprehension. Besides this, when they do disclose financial indicators, this is by way of graphs without further information.

The final $21.43 \%$ of companies stood out for disclosing both social/environmental aspects and financial indices, seeking to respond to the interests of external users.

Finally, in comparing the results obtained by the companies in Espírito Santo with those of CVRD and Embraer, it can be said that the former badly need to improve their publication of financial statements.

\section{GRAPH 1}

Percentage of Companies Disclosing Proposed Information

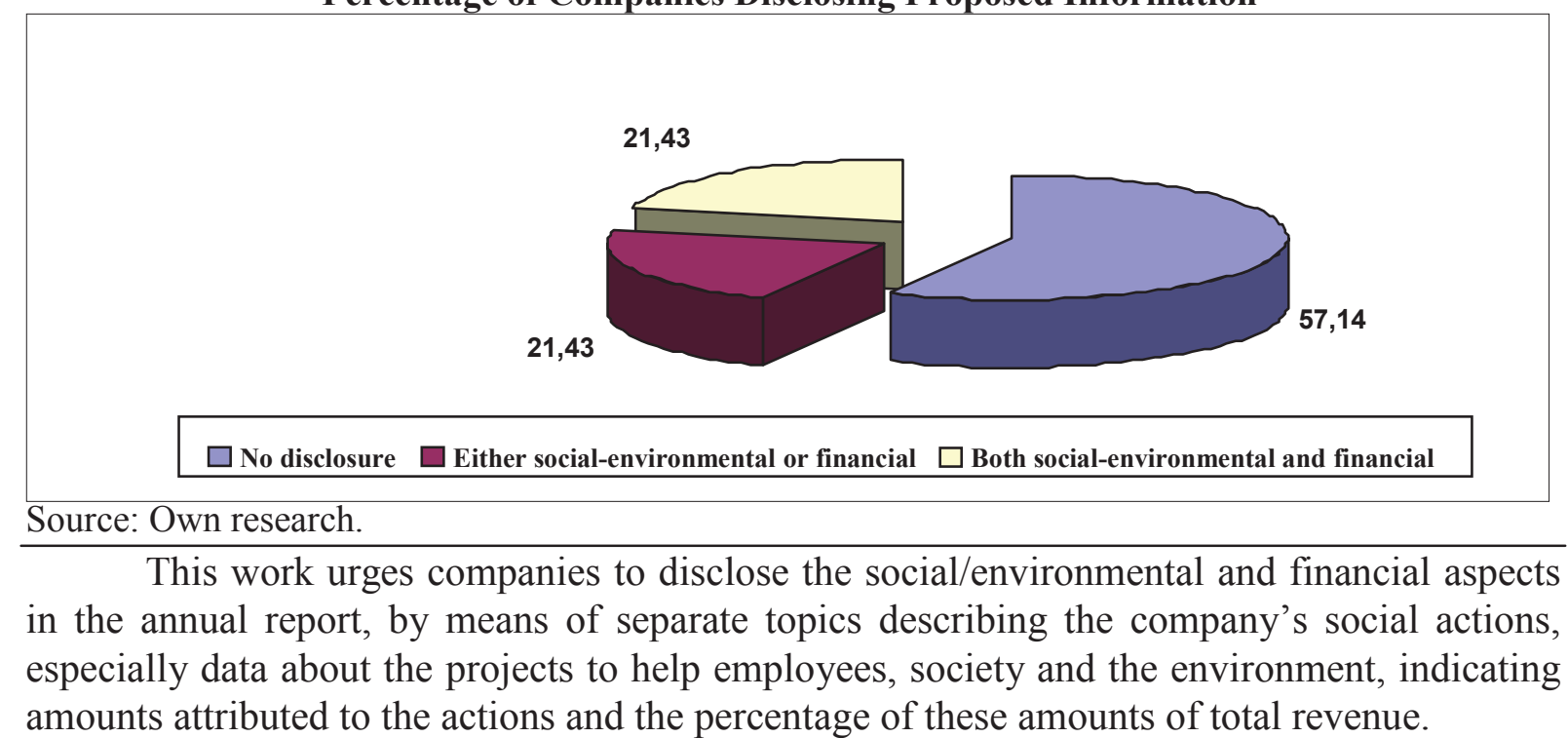


Financial indices can be shown in tables, with percentages for the current and past year. The indices should be chosen by each company from among those most known to external users and that best depict the its economic and financial reality.

It is possible to show this information in notes, using tables and charts as part of the notes. However, if the intention is to reach a large number of readers, with different knowledge levels, it is necessary that these stand out and attract the eye. Users generally look in the notes only for information to clarify doubts about items in the statements, and ignore them when they have no such doubts. Besides this, the notes are generally published at the end of the financial statements, which may not attract the attention they warrant.

\section{FINAL CONSIDERATIONS}

The objectives proposed in this work were attained. Based on the proxies used, it was possible to identify and quantify the percentage of companies in the state of Espírito Santo that are concerned with the quality of the disclosure and those that are not. This work, then, helps awaken these companies to the need for modernization in this respect, for research and an ongoing effort to better satisfy the demands of external users. Nevertheless, there were certain limitations, in that it did not investigate the other side involved - the external users.

The publication of information in an annual report, beyond just simple financial statement, is one of the responses to this problem. Such a report serves to introduce the financial statements and place them in context, whetting interest in readers in learning more about the company. However, it is necessary for the information divulged in the annual report from management not to be mere advertising, not fully truthful or unduly biased. It is essential the report be used ethically, responsibly and transparently by accounting and other professionals.

It is quite difficult for accountants and the companies they work for to know what type and form of disclosing this information is best to Brazilian reality. This work, then, proposes a way to improve disclosure, on social-environmental and financial aspects, but the study of this process of communication between the company and stakeholders and the quality of disclosure still requires further investigation and effort. It is necessary to identify what communication process is most acceptable by users, seeing as how they vary widely in their needs and expertise.

We hope this work will encourage greater awareness among companies that besides the need for new information, they must develop projects and actions to disclose it better.

\section{REFERENCES}

150 Maiores Empresas do Espírito Santo, 2002 Edition, Vitória, no. 6, p. 129. AQUINO, Wagner de, SANTANA, Antonio Carlos de. Evidenciação. São Paulo, Caderno de Estudos da FIPECAFI, June 1992.

ANEFAC. Troféu Transparência. Available at: $<$ http://www.anefac.com.Br/eventos/transp_2002.htm>. Accessed on Oct. 20, 2002. COMISSÃO DE VALORES MOBILIÁRIOSS. Companhias Abertas - Demonstrações

Financeiras Padronizadas. Available at: $<\underline{\text { http: } / / w w w . c v m . g o v . b r}>$. Accessed on April 30, 2003.

CONSELHO FEDERAL DE CONTABILIDADE, Resolution no. 750, of December 29, 1993. Provides the main accounting fundamentals. President: Ivan Carlos Gatti. Diário Oficial da União, Brasília, December 31, 1994.

DE LUCA, Márcia Martins Mendes. Demonstração do Valor Adicionado: do cálculo da riqueza criada pela empresa ao valor do PIB. 1st Edition. São Paulo; Atlas, 1998. 
HENDRIKSEN, Eldon S., BREDA, Michael F. Van. Teoria da Contabilidade. Translated by Antônio Zoratto Sanvicente. São Paulo: Atlas, 1999.

IUDÍCIBUS, Sérgio. Teoria da Contabilidade. 6th Edition. São Paulo: Atlas, 2000. . Análise de Balanços. 7th Edition. São Paulo: Atlas, 1998.

IUDÍCIBUS, Sérgio, MARTINS, Eliseu., GELBECK, Ernesto Rubens. Manual de Contabilidade das Sociedades por Ações - FIPECAFI. 5th Edition. São Paulo: Atlas, 2000. JÚNIOR, José Hernandez Perez., BEGALLI, Glaucos Antonio. Elaboração das Demonstrações Contábeis. 3rd Edition. São Paulo: Atlas, 2002.

LOPES, Alexsandro Broedel. A informação contábil e o mercado de capitais. São Paulo: Pioneira Thomson Learning, 2002.

LOUZADA, Luiz Cláudio. Fatores que influenciam a capacidade de geração, comunicação e Informação das Demonstrações Contábeis. Universo Acadêmico, Nova Venécia, V.2, n.2, pp. 13-32, January-June 2002.

MATARAZZO, Dante Carmine. Análise Financeira de Balanços: Abordagem Básica e Gerencial. 5th Edition. São Paulo: Atlas, 1998.

NASCIMENTO, Dinalva Melo do. Metodologia do Trabalho Científico - Teoria e Prática. 1st Edition. Rio de Janeiro: Forense, 2002. 